THE aim of the study was to analyse the effect of interleukin-4 (IL-4) on allergen and anti-IgE mediated histamine release from basophils and human skin mast cells and to assess whether soluble recombinant interleukin -4 receptor ( $s \mathrm{IL}$ 4R) can inhibit these effects. Anti-IgE stimulated histamine release from peripheral blood basophils and mast cells of atopic donors was enhanced after preincubation with IL 4 , whereas after preincubation with $s I L-\mathcal{R}$ it was inhibited. These effects were even more pronounced when samples were stimulated with a clinically relevant allergen. In IL 4 preincubated skin mast cells, there was a similar enhancement of anti-IgE stimulated histamine release, which could again be inhibited by sIL 4 R. The effects of IL 4 and sIL $4 R$ were dose- and time-dependent. Mice sensitized to ovalbumin and treated with soluble recombinant murine $s I L-4 R$ showed significantly reduced immediate-type cutaneous hypersensitivity responses compared with untreated mice. These in vivo effects were IgE independent, since there were no significant differences in total and allergen specific IgE/IgG1 antibody titres between treated and untreated mice. This indicates that IL4 exerts priming effects on histamine release by effector cells of the allergic response and that these effects are potently antagonized by soluble IL $4 \mathrm{R}$ both in vitro and in vivo.

Key words: Allergy, Basophil, Histamine release, IL 4 , sIL4R, Mast cell, Mice

\section{Interleukin-4 (IL-4) enhances and soluble interleukin-4 receptor (sIL-4R) inhibits histamine release from peripheral blood basophils and mast cells in vitro and in vivo}

\author{
B. Niggemann, ${ }^{1, C A}$ T. Zuberbier ${ }^{3}$ U. Herz, ${ }^{2}$ \\ K. Enssle, ${ }^{4}$ U. Wahn ${ }^{1}$ and H. Renz ${ }^{2}$ \\ ${ }^{1}$ Children's Hospital, ${ }^{2}$ Institute for Clinical Chemistry
and Biochemistry, ${ }^{3}$ Department of Dermatology,
Virchow Clinic of Humboldt University, Berlin,
Germany; ${ }^{4}$ Behringwerke AG, Marburg, Germany
}

${ }^{\mathrm{CA}}$ Corresponding Author

Tel: (+49) 3045066643

Fax: (+49) 3045066931

\section{Introduction}

Interleukin 4 (IL-4) plays a central role in

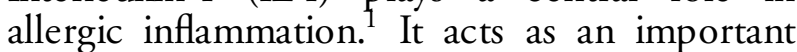
immunoglobulin isotype switch factor for IgE synthesis and is required for initiation and promotion of a TH2 T-cell response. ${ }^{2-5}$ IL4 stimulates expression of endothelial cell adhesion molecules on lymphocytes, ${ }^{6}$ eosinophils, basophils and mast cells. ${ }^{7-9}$ IL 4 production is increased in atopic dermatitis patients ${ }^{10}$ and IgE synthesis induced by IL 4 is enhanced during seasonal allergen exposure. ${ }^{11}$

While there is clear evidence of IL 4 production by Tlymphocytes, some reports raise the possibility of IL4 production by human mast cells ${ }^{12,13}$ and basophils. ${ }^{14}$ Furthermore, human mast cells express IL 4 receptors. ${ }^{15}$ Mast cells and basophils represent important effector cells of the immediate-type allergic response which is characterized by the release of histamine and other mediators upon crosslinking of receptor bound IgE molecules by allergens. The expression of IL 4 receptors on these cells suggests that mast cells and basophils are sensitive to this cytokine. Since little is known about the interaction of IL 4 with effector cells, we examined the potential role of IL 4 on allergen and anti-IgE triggered histamine release from human basophils and skin mast cells. We examined further whether immunomodulation with an IL 4 antagonist would inhibit the IL 4 mediated effects. It has recently been shown that a recombinant soluble IL4 receptor can inhibit many of the IL 4 mediated cell functions both in vitro and in vivo..$^{16,17}$ To examine the biological relevance of these findings, allergen sensitized mice were treated with a murine recombinant soluble IL 4 receptor and the immediate skin response was assessed.

\section{Material and Methods}

\section{Patients}

For experiments on basophils, blood was drawn from 11 adult atopic patients (six women, five men), aged 20-44 years (mean age 33 years). 
Total IgE ranged from 45 to $6650 \mathrm{kU} / \mathrm{l}$ (median $429 \mathrm{kU} / \mathrm{l}$ ). Patients were sensitive to birch pollen (Betula verrucosa) (Bet v) and/or Der$m$ atoph agoides pteronyssinus (Der $\mathrm{p}$ ). Sensitization was proven by specific IgE to birch and/ or house-dust mite in serum (Pharmacia CAPsystem, Uppsala, Sweden). Blood was taken over all the year except during the seasons April/May for birch- and September/October for house dust mite-sensitive patients. All patients suffered from allergic rhinoconjunctivitis, one patient from atopic dermatitis as well. All patients were without any anti-alle rgic medication for at least 4 weeks before drawing blood for the experiments. No patient had any infection during 2 weeks before the study.

Mast cells were prepared from normal human breast skin of six healthy female donors, aged 21-45 years (mean age 29 years), with no history of atopy who were undergoing plastic surgery for cosmetic reasons. All patients gave their informed consent. The study was approved by the local ethics committee.

\section{Reagents and buffer solutions}

The following reagents were purchased: pipes, collagenase type $1 \mathrm{a}$, hyaluronidase type I-S, chicken ovalbumin (OVA) grade V, (Sigma, Deisenhofen, Germany), Dextrane 6\% (Braun, Melsungen, Germany), glucose 40\% (Fresenius, Bad Homburg, Germany), perchloric acid (Merck, Darmstadt, Germany), allergen extract from Der $p$ and Bet $v$ (ALK, Copenhagen, Denmark), IL4 (Dianova, Hamburg, Germany), DNAse (Boehringer, Mannheim, Germany), IgE, HSA (Pfrimmer, Erlangen, Germany), MEM (Earle's salts, fetal calf serum (FCS) (Gibco, Berlin, Germany), anti-IgE (Behring, Marburg, Germany); Pipes A (with $0.025 \%$ HSA), Pipes EDTA (Pipes A with $4 \mathrm{mM}$ EDTA), and Pipes ACM (Pipes A with $2 \mathrm{mM} \mathrm{CaC}_{2}$ and $0.5 \mathrm{mM}$ $\mathrm{Mgd}_{2}$ ) were used in all experiments at a $\mathrm{pH}$ of 7.40. In experiments with human skin mast cells, MEM culture medium was supplemented with $2 \% \mathrm{FCS}, 1 \%$ penicillin and streptomycin, $1 \%$ glutamine, $2 \% \mathrm{MgSO}_{4}$ and $10 \mu \mathrm{g} / \mathrm{ml}$ DNAse.

\section{Human and murine recombinant soluble IL-4 receptor}

Soluble IL4 receptor was prepared as previously described. ${ }^{18}$ Briefly, using cDNA for the extracellular region of human and murine IL$4 \mathrm{R}^{19,20}$ recombinant soluble monomeric forms of IL $4 \mathrm{R}$ (human, rhuIL $4 \mathrm{R}$ and murine, muIL$4 \mathrm{R})$ were constructed. The murine and human forms of rIL $4 \mathrm{R}$ were expressed in BHK cells.
The proteins were purified by affinity chromatography using specific antibodies. Bioactivity, glycosylation and pharmacokinetics in mice were controlled for each lot of the molecules to achieve an uniform reactivity in vitro and in vivo.

\section{Preparation of basophil cultures from peripheral blood}

Basophils were enriched and cultivated as previously described.$^{21}$ Briefly, peripheral blood leukocytes were obtained by spontaneous sedimentation for $60 \mathrm{~min}$ at room temperature. The percentage of viable basophils within the leukocyte preparation ranged between $6 \%$ and $11 \%$ Cells were washed twice with Pipes A/EDTA and centrigued for $10 \mathrm{~min} .1 \times 10^{7}$ leukocytes were placed in $4 \mathrm{ml}$ plastic tubes (Sarstedt, Nümbrecht, Germany) in Pipes EDTA buffer. Cells were preincubated with IL4 (100 to $5000 \mathrm{IU} / \mathrm{ml}$ ), sIL $4 \mathrm{R}(1$ to $200 \mu \mathrm{g} / \mathrm{ml}$ ) or buffer in a water bath at $37^{\circ} \mathrm{C}$ for $2.5 \mathrm{~h}$. After decanting supernatants and washing cells in Pipes A, Pipes ACMwas added and cells were challenged with anti-IgE (30 and $100 \mathrm{IU} / \mathrm{ml})$, Der $\mathrm{p}$ (30 and $100 \mathrm{SQ} / \mathrm{ml})$ or Bet $\mathrm{v}(22$ and $220 \mathrm{ng} / \mathrm{ml})$. After a 30 min incubation at $37^{\circ} \mathrm{C}$, cells were centrifuged for $15 \mathrm{~min}$ and supernatants were stored at $-20^{\circ} \mathrm{C}$ until determination of histamine. All measurements were performed in duplicate.

\section{Preparation of human skin mast cells cultures}

Mast cells were isolated by enzymatic dispersion, with slight modification as previously described. ${ }^{22}$ Briefly, skin was cut into small squares $\left(1-2 \mathrm{~mm}^{2}\right)$, dispersed in two 1 th cycles with collagenase and hyaluronidase $(15 \mathrm{mg}$ and $7.5 \mathrm{mg} / \mathrm{g}$ tissue respectively, $2.5 \mathrm{ml}$ medium $/ \mathrm{g}$ tissue). Undissociated tissue was removed by filtration with nylon gauze $(150 \mu \mathrm{m})$ and thereafter the cells were washed twice in Pipes A. Viability of mast cells was determined by trypan blue staining and mast cell purity was assessed by toluidine blue staining. Viability of mast cells was $>95 \%$ This procedure yielded $6-8 \times 10^{5}$ mast cells/g wet tissue with 3-5\% mast cells of total nucleated cells. After collection of the dissociated cells, these were washed twice with Pipes A and then passively sensitized with $\operatorname{IgE}$ $\left(1 \mu \mathrm{g} / 10^{6}\right.$ cells $)$ at room temperature overnight. The cells were then incubated in Pipes ACM with $10-1000 \mathrm{ng} / \mathrm{ml} \mathrm{IL} 4$ for $5-15 \mathrm{~min}$ at $37^{\circ} \mathrm{C}$ in a water bath, or overnight in medium in an incubator. Aliquots of $10^{4}$ mast cells in $0.4 \mathrm{ml}$ pipes $\mathrm{ACM}$ were challenged in duplicate with 
anti-IgE (1000, 2000 and $4000 \mathrm{IU} / \mathrm{ml}$, with 0.417 IU precipitating $1 \mathrm{ng}$ IgE WHO standard).

\section{Measurement of histamine release}

Spontaneous histamine release, which was determined by the addition of Pipes ACM instead of stimuli, ranged between $5 \%$ and $10 \%$ of total histamine content. Total cellular histamine content was assayed by lysis of cell aliquots with $2 \%$ perchloric acid. After a 20 min incubation at $37^{\circ} \mathrm{C}$, cells were centrifuged and supernatants were stored at $-20^{\circ} \mathrm{C}$ until analysed.

Histamine was determined with an automated fluorometric analyser (Technicon, New York, USA) using a procedure previously described. ${ }^{23}$ Results were only considered where spontaneous histamine release was less than $10 \%$ of total histamine content. More than $80 \%$ of our experiments fulfilled the criteria. For each result, spontaneous histamine release (incubation in Pipes ACM buffer) was subtracted and calculated as a percentage of total histamine content $(=100 \%)$ for each culture condition. The measurements were performed in duplicate.

\section{Allergic sensitization of mice}

$\mathrm{BALB} / \mathrm{c}$ mice (aged 6-10 weeks, from Bomholtgard, Denmark) were sensitized to OVA by nebulization of $1 \%$ ovalbumin (OVA) diluted in PBS. Sensitization was performed by exposure for $20 \mathrm{~min}$ every seventh day. As previously show $\mathrm{n}^{24}$ and confirmed in this study, this procedure stimulated production of allergenspecific $\operatorname{IgE} / \operatorname{IgG} 1$. After 4 weeks, mice were treated five times every other day by $20 \mathrm{~min}$ nebulization of $1 \mathrm{mg}$ sIL $4 \mathrm{R}$ diluted in $7 \mathrm{ml}$ PBS. Skin testing was performed $24 \mathrm{~h}$ after the last treatment. The study was approved by the local Animal Ethics Committee.

\section{Assessment of immediate-type skin tests response in mice}

Intradermal skin tests (ST) were performed as previously described. ${ }^{25}$ Briefly, abdominal skin was shaved and $50 \mu \mathrm{l}$ of test solution was injected intradermally. PBS was used as negative control and compound 48/80 (Sigma, Muinchen, Germany) as positive control. Injection points were separated by at least $1.5 \mathrm{~cm}$ in order to avoid confluence of solutions. Allergen concentration was $50 \mu \mathrm{g} / \mathrm{ml}$ for ovalbumin. Resultant wheal formations were scored in a blinded fashion after $15-20 \mathrm{~min}$ by semiquantitative assessment of skin test reactivity. Reactions with a diameter $\leqslant 1 \mathrm{~mm}$ were scored with 0 points, $2-4 \mathrm{~mm}$ with 1 point and reactions $\geqslant 5 \mathrm{~mm}$ with 2 points. All animals developed positive wheal formations to compound 48/80, none reacted to $\mathrm{PBS}$.

Measurement of total and allergenspecific lgE/lgG1 antibody titres in serum samples

Analysis of total $\mathrm{IgE}$ and anti-OVA IgE/IgG1 antibody titres were determined by ELISA. Briefly, 96-well Ubottom, polystyrene microtitre plates (Greiner, Nürtingen, Germany) were coated either with anti-mouse $\operatorname{IgE}(10 \mu \mathrm{g} / \mathrm{ml})$ (Pharmingen, San Diego, USA) or ovalbumin $(20 \mu \mathrm{g} / \mathrm{ml})$ Sigma, Deisenhofen, Germany) diluted in $0.05 \mathrm{M}$ carbonate coating buffer, $\mathrm{pH}$ 9.6. Plates were incubated overnight, washed three times in washing buffer (PBS/ $0.05 \%$ plus Tween $20, \mathrm{pH} 8.2)$ and blocked for $2 \mathrm{~h}$ at $37^{\circ} \mathrm{C}$ with blocking solution (2\% BSA in PBS). After three washes with washing buffer, samples diluted in PBS/0.4\% BSA were incubated for $2 \mathrm{~h}$ at $37^{\circ} \mathrm{C}$. Washed plates were incubated with biotin-conjugated anti-mouse $\operatorname{IgE} / \mathrm{IgG1}$ monoclonal antibodies for $2 \mathrm{~h}$ at $37^{\circ} \mathrm{C}(2.5 \mu \mathrm{g} / \mathrm{ml})$ (Pharmingen, San Diego, USA) followed by incubation with alkaline phosphate-conjugated streptavidin (1:500) (Jackson Immuno Research Laboratories, West Grove, USA) for $1 \mathrm{~h}$ at $37^{\circ} \mathrm{C}$. Plates were developed with p-NPP substrate $(0.5 \mathrm{mg} / \mathrm{ml})$ (Sigma, Deisenhofen, Germany) and absorbance was measured at $405 \mathrm{~nm}$.

\section{Statistical analysis}

For statistical analysis, we used the Wilcoxon test for paired data, and Mann-Whitney U-test. For all numbers, standard error of mean is given. $P$ values $<0.05$ were considered as statistically significant.

\section{Results}

\section{Modulation of histamine release by} human basophils

In order to investigate the effect of IL 4 on histamine release from human basophils, cells were stimulated with anti-IgE or the clinically relevant allergens. After preincubation with buffer alone, both anti-IgE and allergen enhanced histamine release in a dose-dependent manner, with a peak release at $100 \mathrm{IU} / \mathrm{ml}$ for anti-IgE (percentage of total histamine over background release $32.8 \% \pm 4 \%$ ). The optimal concentration of allergen ranged at $22 \mathrm{ng} / \mathrm{ml}$ for 
Bet v (percentage of total histamine over background release $40.8 \% \pm 4 \%$ and 100 standard quantity units (SQU)/ml for Der $\mathrm{p}$ (percentage of total histamine over background release $27.0 \% \pm 3 \%$ ). Using concentrations lower than $22 \mathrm{ng} / \mathrm{ml}$ Bet $\mathrm{v}$ or $100 \mathrm{SQU} / \mathrm{ml}$ Der p, less pronounced histamine release was measured, which was not significantly different from controls (data not shown).

Cells were preincubated with IL 4 for $2.5 \mathrm{~h}$ followed by stimulation with optimal doses of anti-IgE and allergen. IL 4 enhanced anti-IgE triggered histamine release by $9.5 \% \pm 1.4 \%$ (Fig. 1). However, IL 4 by itself was unable to induce histamine release in the absence of any stimulus. A more pronounced effect was observed on allergen-triggered mediator release. Increases of histamine release by up to $35 \%$ were measured, with a percentage total histamine over background release of $19.0 \% \pm 6 \%$ The reason why we converted the data into values of percentage stimulation/inhibition was the interindividual variability of the patients. We did not find major differences between Bet $\mathrm{v}$ and Der $\mathrm{p}$ effects in our culture system. For this reason, and because the individual groups would have been too small, we decided to present the results of both allergens together in one figure.

Since histamine release by peripheral blood basophils was analysed in the presence of cell subsets capable of secreting II- 4 , and since

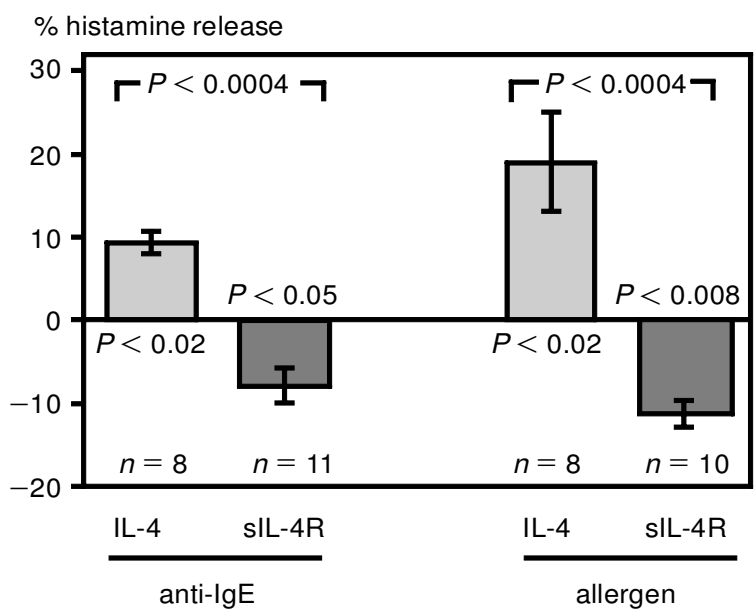

FIG. 1. Effect of IL-4 and sIL-4R on histamine release by peripheral blood basophils. Cells of atopic patients were preincubated with or without either IL-4 $(5000 \mathrm{U} / \mathrm{ml})$ or slL$4 \mathrm{R}(200 \mu \mathrm{g} / \mathrm{ml})$ for $2.5 \mathrm{~h}$ followed by stimulation with either anti-lgE or allergen. Mean percentage of total histamine over background release of anti-lgE stimulated cells was $32.8 \%$, and $40.8 \%$ in allergen stimulated experiments. For each experiment, the percentage of stimulation/inhibition was calculated. Expressed are mean \pm standard error of mean values. Experiments were performed with allergic patients; numbers are indicated in the figure. P-values around the baseline indicate statistical significance in relation to baseline values. enhanced IL-4 production has been demonstrated by peripheral blood lymphocytes from atopic donors, ${ }^{10,11,26}$ it was necessary to determine whether intrinsic ongoing IL-4 production contributed to the priming effect observed in the assay. A soluble recombinant human IL 4 receptor (sIL4R) was added to cultures prior to stimulation with anti-IgE or allergen. Histamine release in peripheral blood basophils stimulated with anti-IgE was inhibited after preincubation with sIL 4 R by $-7.9 \pm 6.5 \%$ (Fig. 1). An even more pronounced reduction was measured when cells were stimulated with allergen (Der p): sIL $4 \mathrm{R}$ inhibited histamine release by up to $20 \%$ with a mean reduction of $11.3 \pm 3.2 \%$ (Fig. 1). This data provides evidence that intrinsic ongoing IL4 secretion by peripheral blood leukocytes exerts priming effects on histamine release by basophils.

Dose-response experiments showed that the effects of IL 4 (Fig. 2A) and sIL4R (Fig. 2B) on both anti-IgE and allergen induced histamine release were dependent on the concentration. However, despite a clear tendency, results failed to reach statistical significance due to small numbers in some concentrations. Maximal augmentation of histamine release was found following preincubation with more than $1000 \mathrm{U} / \mathrm{ml}$ IL 4 ; sIL $4 \mathrm{R}$ at a concentration of $>100 \mu \mathrm{g} / \mathrm{ml}$ resulted in optimal inhibition of histamine release. To assess the specificity of these effects, cells were preincubated with a murine recombinant soluble IL $4 \mathrm{R}$ that does not bind to human IL4. Incubation of leukocytes with murine sIL$4 \mathrm{R}$ in the same dose range was without any effects on anti-IgE or allergen-induced mediator release (data not shown).

Optimal effects were achieved when cells were preincubated with IL 4 and sIL $4 \mathrm{R}$ for about $2.5 \mathrm{~h}$. Preincubation for a shorter period decreased the priming effect of IL 4 (data not shown). When cells were preincubated for a period longer than $3.5 \mathrm{~h}$, spontaneous histamine release significantly $(P<0.05)$ increased and interfered with the assessment of IL $4 / \mathrm{sIL}$ $4 \mathrm{R}$ effects.

\section{Modulation of histamine release from human skin mast cells}

To analyse whether IL 4 would also exert priming effects on other effector cells of the allergic reaction, we examined the effect of IL 4 on mast cells prepared from human non-atopic skin. Mast cells were presensitized with human $\mathrm{IgE}$ and in vitro histamine release was measured following stimulation with anti-IgE There was a significant $(P<0.05)$ enhancement of 
$\%$ stimulation

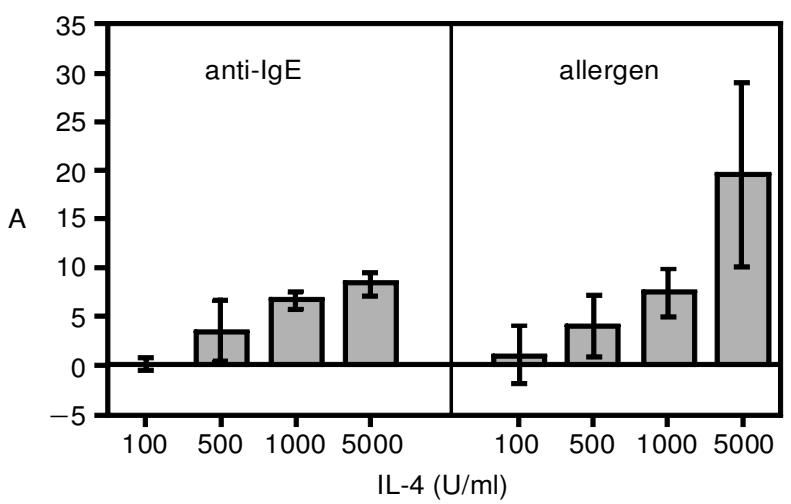

$\%$ inhibition

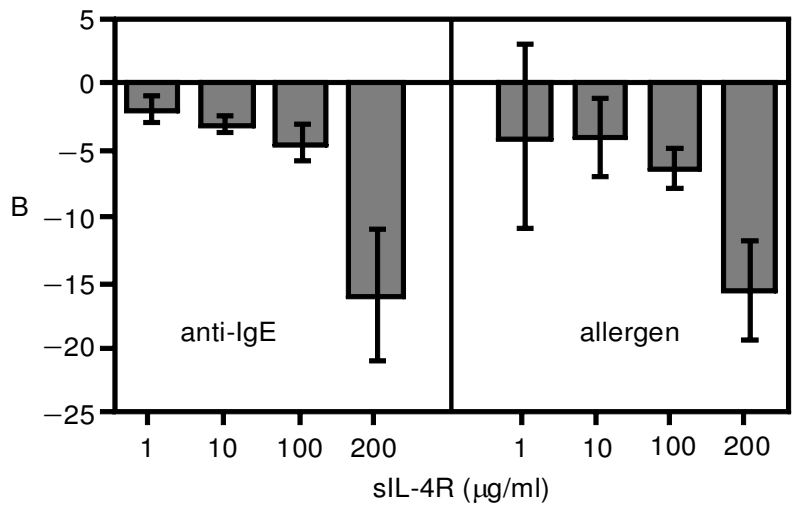

FIG. 2. Stimulation by IL-4 and inhibition by sIL-4R of histamine release. Cells from atopic patients were preincubated with or without IL-4 (100 to $5000 \mathrm{U} / \mathrm{ml})$ (A) or sIL-4R $(1-200 \mu \mathrm{g} / \mathrm{ml})$ (B) for $2.5 \mathrm{~h}$ followed by stimulation with anti-lgE $(100 \mathrm{lU} / \mathrm{ml})$ and allergen $(22 \mathrm{ng} / \mathrm{ml}$ Bet $v$ and $100 \mathrm{SQ} / \mathrm{ml}$ Der p). A total of seven patients was analysed. For each donor, stimulation and inhibition of histamine release were compared with incubation with buffer alone and results are expressed in percentage changes. Expressed are mean \pm standard error of mean values.

anti-IgEtriggered histamine release (from $4.5 \% \pm$ $1.9 \%$ to $8.3 \% \pm 1.9 \%$ following preincubation with IL-4 (Fig. 3). This could be blocked by simultaneous addition of $\operatorname{sIL} 4 \mathrm{R}(n=2$, data not shown).

Inhibition of immediate-type

cutaneous hypersensitivity responses

by treatment with slL-4R

The previous results indicate a priming effect of IL 4 and an inhibitory effect of sIL $4 \mathrm{R}$ on in vitro histamine release. The biological relevance of these findings was evaluated using an animal model of allergic sensitization and $\operatorname{IgE}$ production. ${ }^{27} \mathrm{BALB} / \mathrm{c}$ mice were locally sensitized to ovalbumin via the airways. It has been shown that this procedure results in an increase of allergen-specific $\mathrm{IgE} / \mathrm{IgG} 1$, development of positive skin test responses and enhanced airway responsiveness. ${ }^{25}$ The mice were sensitized
$\%$ histamine release from skin mast cells

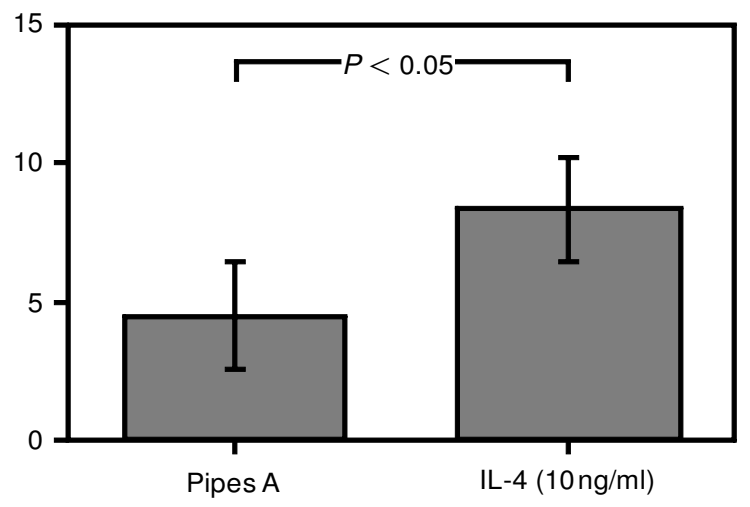

anti-lgE (4000 IU/ml)

FIG. 3. IL-4 enhances anti-lgE induced histamine release from skin mast cells. Mast cells were prepared from the skin of non-atopic individuals $(n=6)$ and sensitized with human $\operatorname{lgE}$. Cells were then preincubated with either Pipes $A$ buffer or IL-4 $(10 \mathrm{ng} / \mathrm{ml})$ followed by stimulation with anti-lgE antibodies $(4000 \mathrm{lU} / \mathrm{ml})$. Expressed are mean \pm standard error of mean values of histamine release. Histamine release was assessed and calculated as described in Material and Methods.

to OVA for 4 weeks followed by a brief period of treatment with murine sIL $4 \mathrm{R}$ also via the airways. The development of allergen specific cutaneous hypersensitivity responses was then assessed by intradermal injection of allergen as described above. As shown in Fig. 4, mice sensitized to OVA via airways and treated by the same route with sILAR developed significantly smaller wheal responses than mice that were

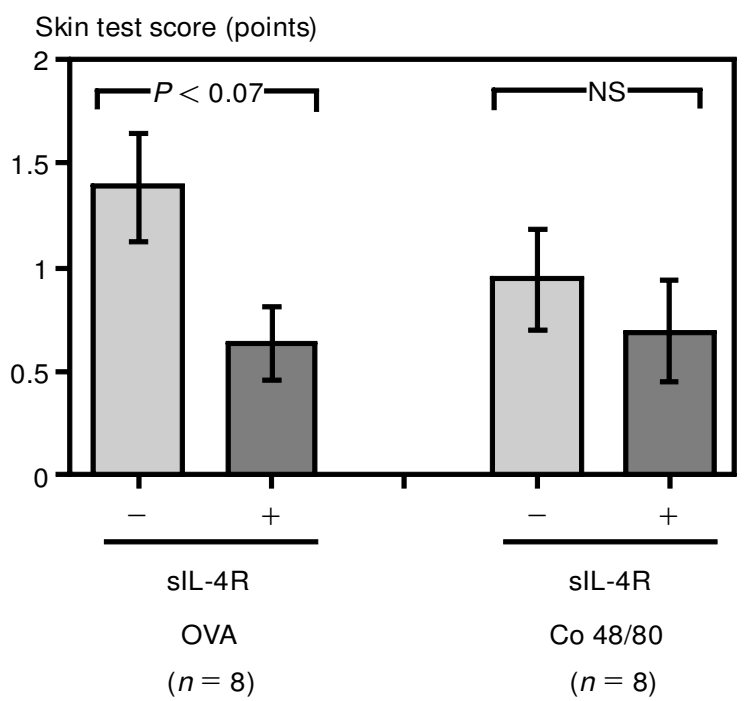

FIG. 4. Skin test response in sIL-4R treated and untreated mice. Mice were sensitized to OVA by aerosolization, then treated with slL-4R via the same route (as described in Material and Methods) and skin tests were performed with OVA, compound 48/80 and PBS. Resultant wheal formations were scored in a blinded manner and results are expressed as mean \pm standard error of mean values. 
not treated with the drug $(P<0.07)$. Inhibition of in vivo mediator release was selective, since wheal formations stimulated by administration of compound 48/80 were not affected. Furthermore, these effects were not related to inhibition of $\mathrm{IgE} / \mathrm{IgG} 1$ production by $s \mathrm{IL}-4 \mathrm{R}$, since total and allergen specific $\operatorname{IgE} / \mathrm{IgG} 1$ concentrations were the same in untreated OVA-sensitized animals (Table 1).

\section{Discussion}

This study provides evidence that IL 4 primes effector cells of the allergic response to release histamine upon stimulation with allergen and anti-IgE. With allergen as the trigger factor for histamine release, mediator release was found to increase by up to $35 \%$ These findings were supported by a similar and significant effect on the development of in vivo immediate-type cutaneous hypersensitivity responses. These results point to a novel function of IL 4 .

IL4 interferes with the allergic response at several levels of regulation: it is associated with the development of Th2 type Tlymphocytes and acts as a growth factor for Th2 cells; $;{ }^{2-5}$ it stimulates $\operatorname{IgE}$ synthesis $^{3-5}$ and is involved in mast cell activation. ${ }^{7-9}$ IL 4 is produced by Tlymphocytes and effector cells including basophils and mast cells. ${ }^{12,13}$ The results of this study indicate that the functional role of IL 4 in allergic inflammatory responses is not restricted to the development of pro-allergic T-and B-cell functions. It also interferes during the effector phase of the allergic response by priming mediator secretion from basophils and mast cells. We measured histamine release by these effector cells, since it represents an important and clinically relevant mediator of the early phase of the immediate-type allergic response. It is likely that secretion of other mediators which are released together with the prototypic mediator histamine is also enhanced under the influence of IL-4.

Since there is increasing evidence for the secretion of IL 4 by mast cells and basophils, ${ }^{28,29}$

Table 1. Serum total IgE, anti-OVA IgE and anti-OVA IgG1 in mice treated with sIL-4R in comparison with untreated animals $(n=16)$. Results (day 36 ) are expressed as mean \pm SD

\begin{tabular}{lccc}
\hline & $\begin{array}{c}\text { Treatment } \\
- \text { slL-4R }\end{array}$ & $\begin{array}{c}\text { Treatment } \\
+ \text { slL-4R }\end{array}$ & $\mathrm{P}$ \\
\hline Total IgE (O.D.) & $0.31 \pm 0.17$ & $0.29 \pm 0.19$ & $\mathrm{NS}$ \\
Anti-OVA IgE (O.D.) & $0.27 \pm 0.10$ & $0.24 \pm 0.10$ & $\mathrm{NS}$ \\
Anti-OVA IgG1 (O.D.) & $0.41 \pm 0.36$ & $0.41 \pm 0.35$ & $\mathrm{NS}$ \\
\hline
\end{tabular}

O.D. = optical density. one can envisage a multidirectional activity of IL 4 during the development of immediate-type I allergic reactions. If IL 4 is released upon crosslinking of membrane-bound $\mathrm{IgE}$ antibodies, this source of IL 4 may prime neighbouring effector cells to release higher amounts of histamine (and other mediators). Therefore, IL-4 would potentiate the development of the allergic response in an autocrine and paracrine fashion. In our experiments it is possible that preactivated mast-cells and/or basophils were the source of IL 4 production.

Exactly how IL4 primes effector cells requires further clarification. It is possible that it triggers the release of preformed mediators which are stored in cytoplasmic vesicles. Since IL 4 acts relatively quickly (the priming effects reached optimal levels within $2.5 \mathrm{~h}$ ) it is unlikely that IL-4 increases histamine synthesis by regulation of transscriptional and/or translational events.

In skin mast cells, histamine releasability is generally lower than in basophils. ${ }^{30}$ The enhancement of anti-IgE induced histamine release observed here was in the range of $4.5 \%$ mean histamine release before and $8.3 \%$ after pretreatment with IL 4 . Although these differences may appear low, this represents an $80 \%$ increase of histamine release, which could be biologically relevant considering that the differences observed in anti-IgE induced basophil histamine release between normal controls and asthmatics appear low as well (median histamine release $20 \%$ vs. $26 \%$. $^{31}$

The effects of IL 4 were inhibited in vitro and in vivo by a recombinant soluble IL 4 receptor. We have shown in a previous study that treatment with sIL-4R can inhibit many IL-4 mediated functions under certain experimental conditions. ${ }^{32}$ For example, when BALB/c mice were treated with sIL 4 R simultaneously to allergen sensitization, it inhibited the development of $\mathrm{IgE} / \mathrm{IgG} 1$ production and therefore the induction of immediate-type allergic reactions, including postive immediate-type skin test responses, and also increased airway responsiveness. We concluded from that study that the effects of sIL $4 \mathrm{R}$ treatment were related to a functional interference at the level of $\mathrm{T}-\mathrm{B}$ cell interaction. To study whether sIL $4 \mathrm{R}$ would also act directly on the effector phase of the allergic response, we modified the sensitization and treatment protocol. Sensitized mice were treated with the receptor via nebulization for a short time prior to analysis of skin test reactivity. In the present study, the drug was delivered via the airways since it has recently been shown that local administration was superior to systemic treat- 
ment in terms of the inhibitory effects of immediate hypersensitivity responses. ${ }^{33}$

It is unlikely that the in vivo effects of sIL $4 \mathrm{R}$ in our study design were due to down-regulation of $\operatorname{IgE} / \mathrm{IgG} 1$ production, because mice were already sensitized at the time the treatment was started and because the treatment was carried out over a short period of time. In addition, it is likely that $\mathrm{Ig}$ was already bound to $\mathrm{IgE}$ receptors on effector cells and it is suggested that receptor bound $\operatorname{IgE}$ has a long halfflife time. In fact, measurement of $\operatorname{IgE} / \mathrm{IgG} 1$ antibody titres indicated that there were no differences between sIL $4 \mathrm{R}$ treated and untreated mice. It is therefore likely that the effects observed in treated mice were related to a down-regulation of histamine release. SIL $4 \mathrm{R}$ treated mice still developed wheal formations immediately following allergen application into the skin, but the wheals were significantly smaller to a degree that reflects the results of the in vitro experiments. However, it should also be considered that IgE-mediated allergic sensitization to systemic allergen can occur in the absence of circulating $\mathrm{IgE}$. In addition, a direct correlation exist between increased $\mathrm{IgE}$ production and mast cell activation.

In conclusion, this study provides evidence for a new functional activity of IL 4 as a cytokine which primes effector cells of the allergic response to release histamine upon stimulation with allergen. This activity underscores the important and multidirectional activities of this cytokine in the regulation of many aspects of the immunopathogenesis of allergic inflammatory responses. IL 4 not only controls the development of pro-allergic T-cell functions and triggers production of $\mathrm{IgE}$, but also acts on effector cells of the allergic response. The biological relevance of these functions was demonstrated in sensitized mice which were treated with recombinant murine sIL $4 \mathrm{R}$. The treatment study elucidated two important aspects: firstly, the development of in vivo immediate cutaneous hypersensitivity responses is directly controlled by IL 4 , and, secondly, sIL$4 \mathrm{R}$ represents a potent immuno-pharmacological inhibitor for this (and other) functional activities of IL 4 .

\section{References}

1. Ricci M. IL4: a key cytokine in atopy. Clin Exp Allergy 1994; 24: $801-$ 812.

2. Del Prete G, Maggi E, Parronchi P, Chrétien I, Tiri A, Macchia D, Ricci M, Banchereau J, De Vries J, Romagnani S. IL4 is an essential factor for the synthesis induced in vitro by human $\mathrm{T}$ cell clones and their supernatants. J Im mu nol 1988; 140: 4193-4198.

3. Jabara HH, Ahern DJ, Vercelli D, Geha RS. Hydrocortisone and IL4 induce $\mathrm{IgE}$ isotype switching in human B cells. J Immunol 1991; 147: $1557-1560$.

4. Lebman DA, Coffman RL. Interleukin 4 causes isotype switching to IgE in T cell-stimulated clonal B cell cultures. J Exp Med 1988; 188: $853-$ 862

5. Finkelman FD, Katona IM, Urban JF Jr, Holmes J, Ohara J, Tung AS, Sample JvG, Paul WE. IL4 is required to generate and sustain in vivo IgE responses. J Im munol 1988; 141: 2335-2341.

6. Galéa P, Thibault G, Lacord M, Bardos P, Lebranchu Y. IL4, but not tumor necrosis factor- $\alpha$, increases endothelial cell adhesiveness for lymphocytes by activating a cAMP-dependent pathway. I Immunol 1993: 151: 588-596.

7. Schleimer RP, Sterbinsky SA, Kaiser J, Bickel CA, Klunk DA, Tomioka K, Newman W, Luskinskas FW, Gimbrone MA Jr, McIntire BW, Bochner BS. IL 4 induces adherence of human eosinophils and basophils but not neutrophils to endothelium. J Immunol 1992; 148: 1086-1092.

8. Dubois GR, Bruijnzeel-Koomen CAFM, Bruijnzeel PLB. IL4 induces chemotaxis of blood eosinophils from atopic dermatitis patients, but not from normal individuals. J Invest Derm atol 1994; 102: 843-846.

9. Valent P, Bevec D, Maurer D, Besemer J, Di Padova F, Butterfield JH, Speiser W, Majdic O, Lechner K, Bettelheim P. Interleukin 4 promotes expression of mast cell ICAM-1 antigen. Proc Natl Acad Sci 1991; 88: $3339-3342$.

10. Jujo K, Renz H, Abe J, Gelfand EW, Leung DYM. Decreased interferon gamma and increased interleukin 4 production in atopic dermatitis promotes IgE synthesis. JAllergy Clin Immunol 1992; 90: 323-331.

11. Gagnon R, Lian J, Boutin Y, Hébert J. Seasonal enhancement of IL4 induced IgE synthesis by peripheral blood mononuclear cells of atopic patients. Clin Exp Allergy 1993; 23: 498-503.

12. Bradding P, Feather IH, How arth PH, Mueller R, Roberts JA, Britten K, Bews JPA, Hunt TC, Okayama Y, Heusser CH, Bullock GR, Church MK, Holgate ST. Interleukin 4 is localized to and released from human mast cells. J Exp Med 1992; 176: 1381-1386.

13. Brunner T, Heusser CH, Dahinden CA. Human peripheral blood basophils primed by interleukin 3 (IL-3) produce IL4 in response to immunoglobulin E receptor stimulation. J Exp Med 1993; 177: 605611

14. Schroeder JT, MacGlashan DW, Kagey-Sobotka A, White JM, Lichtenste in LM. IgE-dependent IL 4 secretion by human basophils. J Im munol 1994; 153: 1808-1817.

15. Valent P, Besemer J, Kishi K, Di Padova F, Geissler K, Lechner K, Bettelheim P. Human basophils express interleukin4 receptors. Blood 1990; 76: $1734-1738$.

16. Maliszewski CR, Sato TA, van den Bos T, Waugh S, Dower SK, Slack J, Beckmann MP, Grabstein $\mathrm{KH}$. Recombinant soluble receptors specifically inhibit IL-1 and IL 4 induced B cell activities in vitro. J Im munol 1990; 144: 3028-3033.

17. Garrone P, Djossou O, Galizzi JP, Bancherau J. A recombinant extracellular domain of the human interleukin 4 receptor inhibits the biological effects of interleukin 4 on T and B lymphocytes. Eur J Immunol 1991; 21: 1365-1369.

18. Renz H, Enssle K, Lauffer L, Kurrle R, Gelfand EW. Inhibition of allergen-induced $\operatorname{IgE}$ and $\mathrm{IgG} 1$ production by soluble IL 4 receptor. Int Arch Allergy Immunol 1995; 106: 46-54.

19. Idzerda RL, March CJ, Mosley B, Lyman SD, Van den Bos T, Gimpel SD, Din WS, Grabste in KH, Widmer MD, Park LS, et al. Human interleukin4 receptor confers biological responsiveness and defines a novel receptor superfamily. J Exp Med 1990; 171: 861-873.

20. Mosley B, Beckmann MP, March CI, Idzerda RL, Gimpel SD, Van den Bos T, Friend D, Alpert A, Anderson D, Jackson J, Wignall JM, Smith C, Gallis B, Sims JE, Urdal D, Widmer MB, Cosman D, Park LS. The murine interleukin 4 receptor: molecular cloning and characterization of secreted and membrane bound forms. Cell 1989; 59: 335-348.

21. Wahn U, Ernsting M, Peterson J. Spontaneous histamine release from washed leucocytes and whole blood in atopic and non-atopic individuals. Allergy 1990; 45: 109-114.

22. Lowman MA, Rees PH, Benyon RC, Church ML Human mast cell heterogeneity: histamine release from mast cells dispersed from skin, lung, adenoids, tonsils, and colon in response to IgE-dependent and nonimmunologic stimuli. J Allergy Clin Im munol 1988; 81: 590-597.

23. Siraganian RP. Refinements in the automated fluorometric histamine analysis system. J Im munol Meth 1975; 7: 283-290.

24. Renz H, Smith HR, Henson JE, Ray BS, Irvin CG, Gelfand EW. Aerosolized antigen exposure without adjuvant causes increased IgE production and increased airway responsivesness in the mouse. JAllergy Clin Immunol 1992; 89: $1127-1138$.

25. Saloga J, Renz H, Lack G, Bradley KL, Greenstein JL, Larsen G, Gelfand EW. Development and transfer of immediate cutaneous hypersensitivity in mice exposed to aerosolized antigen. J Clin Invest 1993; 91: $133-$ 140.

26. Tang M, Kemp A, Varigos G. IL4 and interferon-gamma production in children with atopic disease. Clin Exp Im munol 1993; 92: 120-124.

27. Larsen GL, Renz H, Loader JE, Bradley KL, Gelfand EW. Airway response to electrical field stimulation in sensitized inbred mice. J Clin Invest 1992; 89: 747-752.

28. Aoki I, Kinzer C, Shirai A, Paul WE, Klinman DM IgE receptor positive 
non-B/non-T cells dominate the production of interleukin 4 and interleukin 6 in immunized mice. Proc Natl Ac ad Sci USA 1995; 92: $2534-2538$.

29. Schroeder JT, MacGlashan DW, Kagey-Sobotka A, White JM, Lichtenstein LM. IgE-dependent IL4 secretion by human basophils. J Imm unol 1994; 153: $1808-1817$.

30. Casolaro V, Spadaro G, Marone G. Human basophil releasability. VI. Changes in basophil releasability in patients with allergic rhinitis or bronchial asthma. Am Rev Respir Dis 1990; 142: 1108-1111.

31. Lichey J, Zuberbier T, Luck W, Lau S, Wahn U. Influence of glycosphingolipids on the release of histamine and sulfidopeptide leukotrienes from human basophils. Int Arch Allergy Immunol 1994; 103: $252-259$.

32. Renz H, Bradley K, Enssle KH, Loader JE, Larsen GL, Gelfand EW. Prevention of the development of immediate hypersensitivity and airway responsiveness following in vivo treatment with soluble IL-4 receptor. Int Arch Allergy Im munol 1996; 109: 167-176.

33. Lack G, Renz H, Saloga J, Bradley KL, Loader J, Leung DYM, Larsen G, Gelfand EW. Nebulized but not parenteral IFN- $\gamma$ decreases IgE production and normalizes airway function in a murine model of allergen sensitisation. J Immunol 1994; 152: 2546-2554.

ACKNOWLEDGEMENTS. This work was supported by the 'Deutsche Forschungsgemeinschaft' (grant Re 737/4-1 and 4-2 to H.R.).

The authors thank Petra Dietl, Gabriele Schulz and Christiane Seib for excellent technical assistance.

\section{Received 5 November 1996;}

accepted in revised form 28 November 1996 


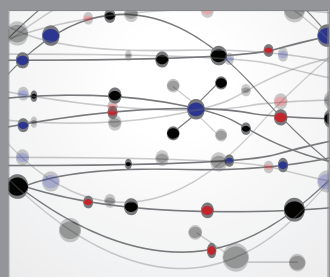

The Scientific World Journal
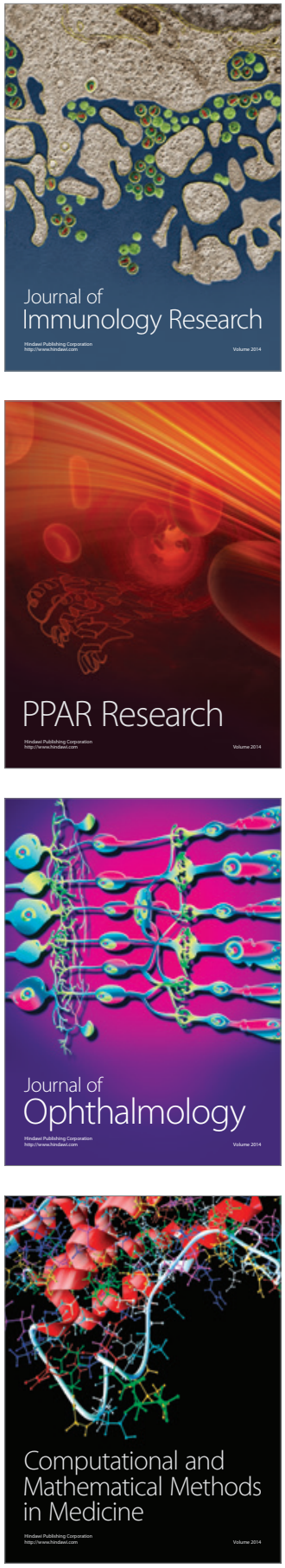

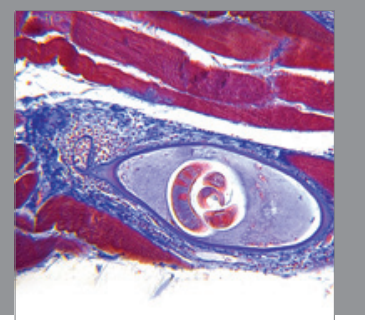

Gastroenterology

Research and Practice
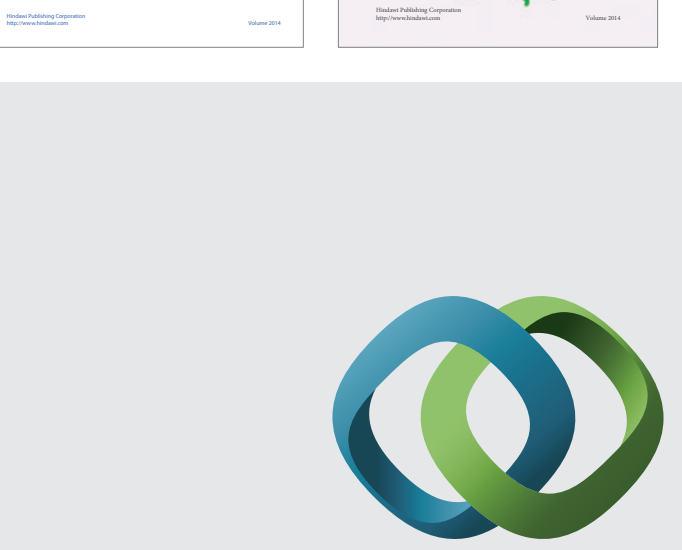

\section{Hindawi}

Submit your manuscripts at

http://www.hindawi.com
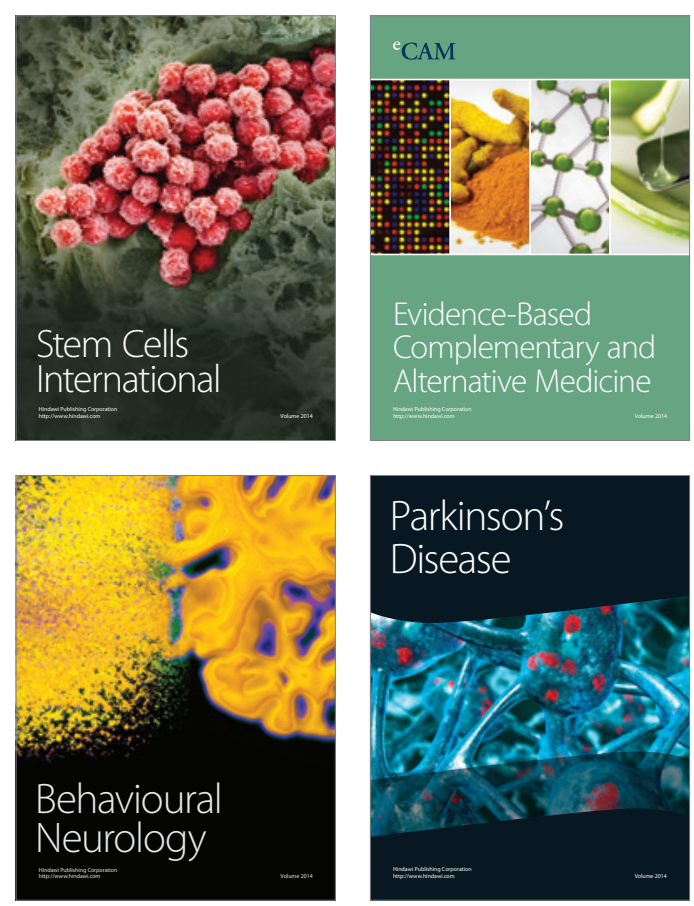

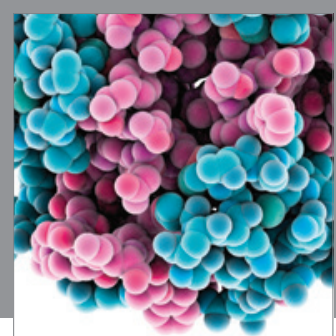

Journal of
Diabetes Research

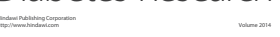

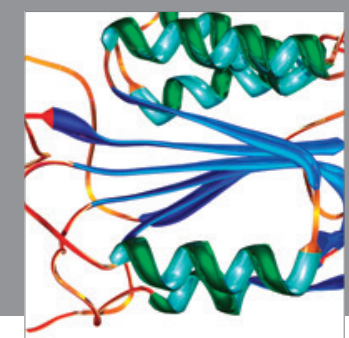

Disease Markers
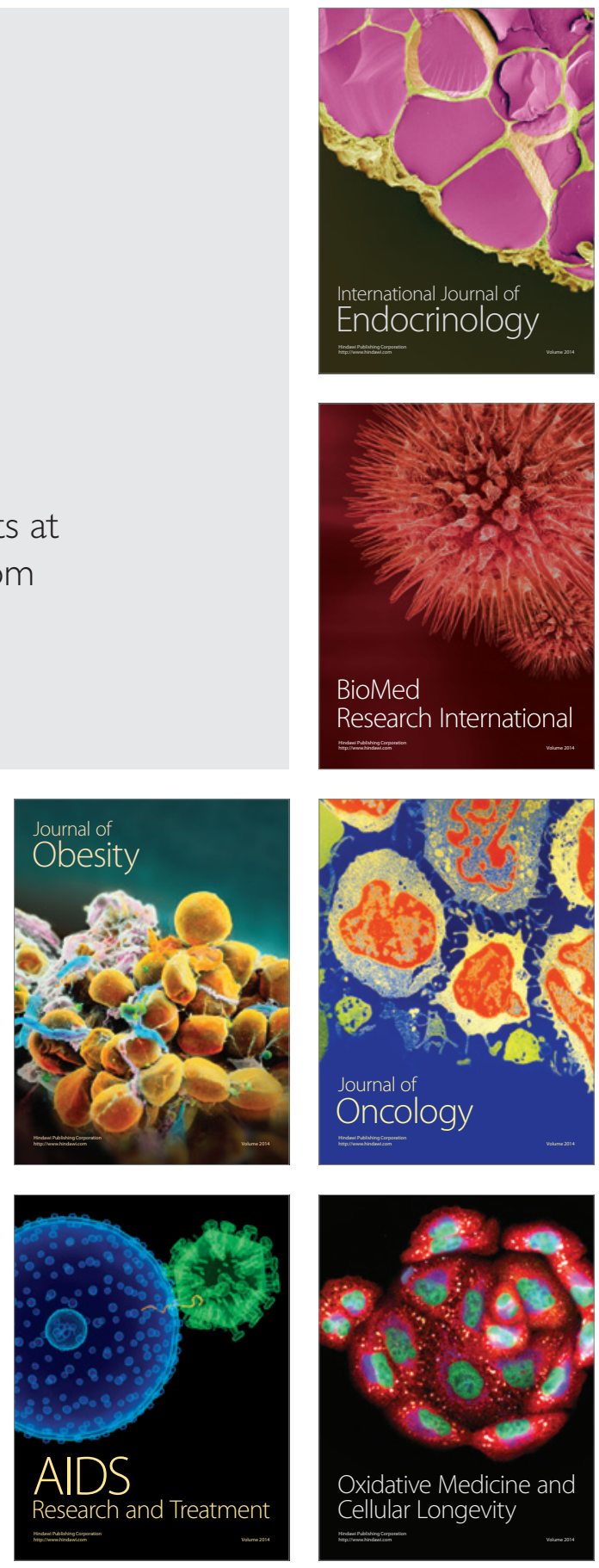